\title{
Effect of Website Quality on E-satisfaction
}

\author{
Hsin-Jung Hsieh \\ Economics \& Management College, Zhaoqing University, China \\ hsi365@live.com
}

\begin{abstract}
Keywords: Website quality, E-satisfaction, Website design.
\end{abstract}
\begin{abstract}
With the growing number of customers purchasing from shopping websites, it is imperative for retail owners to develop a clear understanding of the interactive effects between website quality and online customers. As a means of measuring website quality, a generic model must be developed. The purpose of this research is to explore the relationship between website quality and e-satisfaction. The researcher divided website quality into system quality, information quality, service quality, and design quality. Multiple regression was employed to exam the hypothesis. This study finally supported website quality was the significant, positive explanatory variable of e-satisfaction. The discussion and recommendation for site owners are also included.
\end{abstract}

\section{Introduction}

The effectiveness and success of websites depend on how consumers perceive their value and quality [1]. However, website owners don't know how to effectively evaluate the quality of the website. Few studies have focused on shopping sites to explore how website quality affects consumer behavior. The general purpose of this research is to develop an integrated framework that can explain and guide successful website quality. Such a framework may benefit research in website quality and also assist online stores in evaluating the effectiveness of their websites. The specific purpose of this correlational research is to investigate the effect of website quality on e-satisfaction.

\section{Literature review}

\subsection{Website quality}

Numerous researchers have proposed different dimensions to measure website quality. Sun et al. proposed that website quality can be categorized into three levels, technical service quality, content service quality, and customer service quality [2]. Ahn et al. indicted that website quality includes multiple dimensions, which can be classified into information quality, system quality, and service quality [3]. Moreover, the website quality is perceived by the consumer as to how the website looks and how it works, especially when compared to other websites [4]. Therefore, the evaluation of website quality not only aimed at technology and service but also visual appeal and design.

The following further develops the content and theoretical grounding of website quality. System quality refers to the performance of the website system in terms of usability, availability, reliability, adaptability, and response time [5]. Information quality includes accuracy, relevancy, and completeness of the information provided on the website [6]. It also should be of appropriate scope and depth and present [7]. Service quality concerns the human involvement aspect in terms of responsiveness and empathy [2]. Moreover, high-quality website design means the website has easy navigation, attractive appearance, and appropriate style, and it conveys a sense of competency [8].

\subsection{E-satisfaction}

E-satisfaction is one of the most significant consumer reactions in the B2C online environment [9]. It is also a key factor leading to customer loyalty and makes a long term repurchase relationship between customer and business [2]. When the online environment exceeds the expectations of customers, they will feel satisfied. Besides expectations, more and more scholars refer that product and service quality will also affect the customer satisfaction directly [10]. Some scholars believe that 
e-satisfaction depends on the evaluation of prior online purchase decisions [11]. Moreover, e-satisfaction is also an emotional response from the online relationship between the customer and the company [12].

\section{Hypothesis development}

Most researchers focus on website quality in system, information, and service, and few studies put design quality into research models. This study integrated different terminologies used by various authors in describing the website quality, and then categorized the website quality as system quality, information quality, service quality, and design quality. Previous scholars have proposed that website quality can directly affect customer satisfaction and lead to purchase intention [13]. Therefore, this study hypothesizes that there is a significant explanatory relationship between website quality (system quality, information quality, service quality, and design quality) and e-satisfactory.

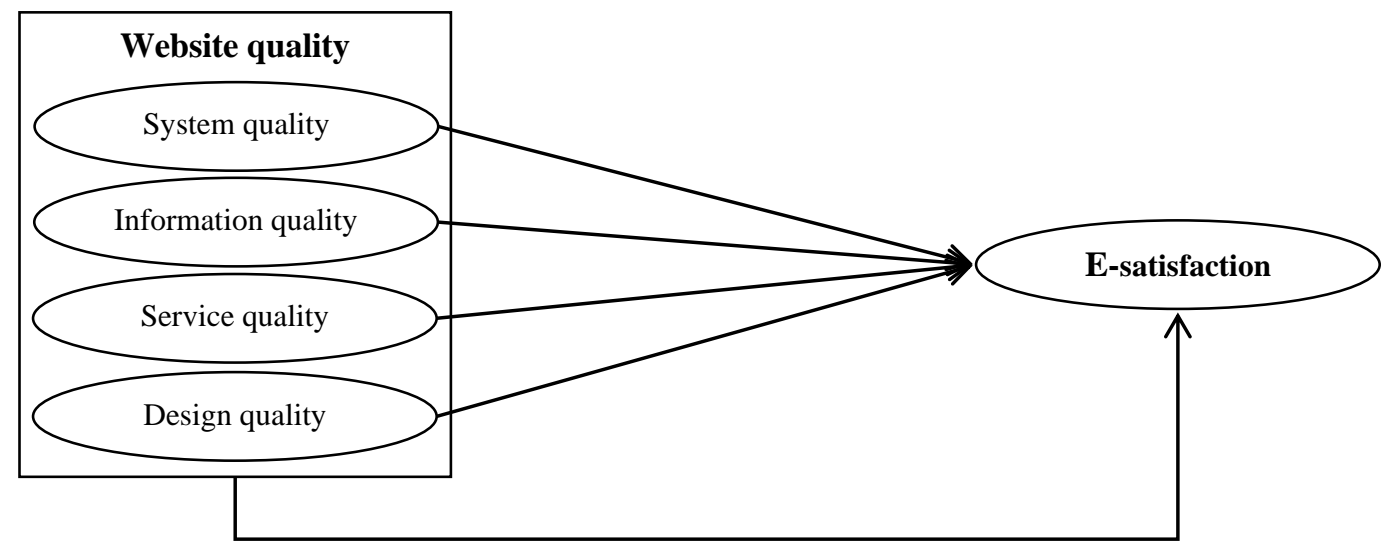

Fig. 1. Hypothesized model

\section{Results}

A self-report, online survey completed by Yahoo! Shopping customers used in this study. Respondents were asked to indicate their answers to each item measured by a five-point semantic differential scale, anchored with $1=$ "strongly disagree" and $5=$ "strongly agree. The following shows the results of the statistical analysis.

\subsection{Exploratory factor analysis and internal consistency reliability analysis}

In this study, exploratory factor analysis was conducted on the scale to further establish construct validity. All items loaded onto a factor at .4 or greater. Coefficient alphas were examined to produce estimates of internal consistency reliability for all scales. The coefficient alpha values exceeded the minimum standard of .7.

Table 1. Factor Loadings and Reliability

\begin{tabular}{|c|c|c|c|c|}
\hline Construct & Items & Factor loading & Cronbach's $\alpha$ & Mean \\
\hline \multirow{5}{*}{ System quality } & Sy1 & .810 & \multirow{5}{*}{.901} & \multirow{5}{*}{3.78} \\
\hline & Sy2 & .740 & & \\
\hline & Sy3 & .739 & & \\
\hline & Sy4 & .639 & & \\
\hline & Sy5 & .630 & & \\
\hline \multirow{4}{*}{ Information quality } & In1 & .651 & \multirow{4}{*}{.912} & \multirow{4}{*}{3.70} \\
\hline & In2 & .763 & & \\
\hline & In3 & .781 & & \\
\hline & In4 & .620 & & \\
\hline \multirow{3}{*}{ Service quality } & Se1 & .786 & \multirow{3}{*}{.845} & \multirow{3}{*}{3.52} \\
\hline & $\mathrm{Se} 2$ & .758 & & \\
\hline & $\mathrm{Se} 3$ & .757 & & \\
\hline
\end{tabular}




\begin{tabular}{|c|c|c|c|c|}
\hline Construct & Items & Factor loading & Cronbach's $\alpha$ & Mean \\
\hline & $\mathrm{Se} 4$ & .717 & & \\
\hline \multirow{4}{*}{ Design quality } & De1 & .715 & \multirow{4}{*}{.877} & \multirow{4}{*}{3.63} \\
\hline & De2 & 709 & & \\
\hline & De3 & .704 & & \\
\hline & De4 & .649 & & \\
\hline \multirow{5}{*}{ E-satisfaction } & Es1 & .538 & \multirow{5}{*}{.810} & \multirow{5}{*}{3.48} \\
\hline & Es2 & .855 & & \\
\hline & Es3 & 842 & & \\
\hline & Es4 & .803 & & \\
\hline & Es5 & .722 & & \\
\hline
\end{tabular}

\subsection{Convergent validity and multiple regression analysis}

Convergent validity was established among all subscales using Pearson $r$ correlation coefficients. As shown in Table 2, significant relationships were found among all subscales. Multiple regression analysis was employed to examine the relationship between website quality variables and e-satisfaction. As shown in Table 3, the $F$ value (51.747) for the overall regression equation was significant $(\mathrm{p}=.000)$. The adjusted $\mathrm{R} 2$ indicated the regression equation using the website quality variables explained $50.0 \%$ of the variation in e-satisfaction.

Table 2. Pearson r Inter Correlations

\begin{tabular}{l|c}
\hline & E-satisfaction \\
\hline Website quality & $.434 * * *$ \\
\hline System quality & $.242 * * *$ \\
\hline Information quality & $.289 * * *$ \\
\hline Service quality & $.507 * * *$ \\
\hline Design quality & $.351 * * *$ \\
\hline
\end{tabular}

Table 3. Summarized Multiple Regression Analysis

\begin{tabular}{lccccc}
\hline Variable & $\mathrm{B}$ & $\mathrm{SE}$ & $\beta$ & $\mathrm{t}$ & $\mathrm{p}$ \\
\hline (Constant) & 10.706 & 6.525 & & & \\
System quality & 1.563 & .237 & .295 & 3.969 & .000 \\
Information quality & 1.933 & .433 & .338 & 4.465 & .000 \\
Service quality & 2.854 & .349 & .639 & 8.181 & .000 \\
Design quality & 1.402 & .199 & .539 & 7.057 & .000 \\
\hline
\end{tabular}

Dependent variable: E-satisfaction

\section{Discussion and conclusion}

\subsection{Discussion}

The researcher divided website quality into four dimensions, system quality, information quality, service quality, and design quality. The dimension with the highest rated score was system quality, followed by information quality, design quality, and service quality. In terms of the relative importance of e-satisfaction, the order of importance was service quality, followed by design quality, information quality, and system quality. In summary, the overall model was the significant in supporting the hypothesis. Website quality was significant, positive explanatory variable of e-satisfaction.

\subsection{Conclusion}

Through adding to the professional literature, this study helps owners of the online store to define their website quality more clearly, and to lead their customer strategies more effectively. Now, some examples in this study are presented:

1. To enhance e-satisfaction, the owner of the website should place greater emphasis on improving website service quality. In particular, it must fully demonstrate personal care and attention, not just responding to customer requests.

2. Web designers should make web pages more interesting and engaging. When online customers find sites interesting, their interaction with the site will increase and they will be positive about the site. 
3. Male consumers are sensitive to system quality, but women are information quality. Therefore, developing system quality is an effective means of improving the e-satisfaction of male consumers. In contrast, information quality should be developed for female customers.

\section{References}

[1] X. Zhang and V. R. Prybutok, A consumer perspective of e-service quality, IEEE Transactions on Engineering Management, vol.52, pp. 461-477, 2005.

[2] J. Sun, Z. Yang, Y. Wang, and Y. Zhang, Rethinking E-Commerce Service Quality: Does Website Quality Still Suffice?, Journal of Computer Information Systems, vol.55, pp. 62-72, 2015.

[3] T. Ahn S. Ryu, I. Han, The impact of Web quality and playfulness on user acceptance of online retailing, Information \& Management, vol.44, pp. 263-275, 2007.

[4] J. Wu and Y. Chang, Towards understanding members' interactivity, trust, and flow in online community, Industrial Management \& Data Systems, vol.105, pp. 937-954, 2005.

[5] W. H. DeLone and E. R. McLean, Measuring e-commerce success applying the DeLone and McLean information systems success model, Information Journal of Electronic Commerce, vol.9, pp. 31-47, 2004.

[6] R. Ladhari and A. Leclerc, Building loyalty with online financial services customers: Is there a gender difference?, Journal of Retailing and Consumer Services, vol.20, pp. 56-59, 2013.

[7] M. Tarafdar and J. Zhang, Analysis of critical website characteristics: A cross-category study of successful websites, Journal of Computer Information Systems, vol.46, pp. 15-24, 2006.

[8] C. Shchiglik and S. J. Barnes, Evaluating website quality in the airline industry, Journal of Computer Information Systems, vol.44, pp. 17-25, 2004.

[9] C. M. Cheung and M. K. Lee, The asymmetric effect of web site attribute performance on web satisfaction: An empirical study, E-Service Journal, vol.3, pp. 65-86, 2005.

[10]T. Sheng and C. Liu, An Empirical Study on the Effect of E-service Quality on Online Customer Satisfaction and Loyalty, Nankai Business Review International, vol.1, pp. 273-283, 2010.

[11]K. Abrar, S. Zaman, and Z. W. Satti, Impact of Online Store Atmosphere, Customized Information and Customer Satisfaction on Online Repurchase Intention, GMJACS, vol.7, pp. 22-34, 2017.

[12]E. Toufaily, M. Arcand, J. Legault, and L. Ricard, The roles of website characteristics and social network communities in developing customer e-loyalty in the online travel industry, Journal of Tourism \& Hospitality, vol.5, pp. 222-233, 2016.

[13]C. D. Chen and C. J. Cheng, Understanding consumer intention in online shopping: A respecification and validation of the DeLone and McLean model, Behaviour \& Information Technology, vol.28, pp. 335-345, 2009. 